DOI: 10.17951/en.2019.4.81-93

\begin{tabular}{lcr}
\hline & ANNALES \\
& & \\
UNIVERSITATIS MARIAE CURIE-SKLODOWSKA & \\
LOL. IV & SECTIO N & 2019 \\
\hline
\end{tabular}

Krzysztof Szewior

Uniwersytet Warszawski

ORCID: http://orcid.org/0000-0003-2455-553X

krzysztofszewior@gmail.com

\title{
Pomiędzy ewaluacją i akredytacją. Polska percepcja niemieckich doświadczeń w kontekście polityk publicznych
}

\author{
Between Evaluation and Accreditation. Polish Perception \\ of German Experience in the Context of Public Policies
}

\begin{abstract}
Streszczenie: W artykule została podjęta próba zaprezentowania kluczowych aspektów odnoszących się do ewaluacji i akredytacji w niemieckim szkolnictwie wyższym, jakie ujawniły się w okresie implementacji procedur akredytacyjnych i budowania ogólnokrajowego systemu nadzoru. Istotą rozważań było wykazanie relacji pomiędzy ewaluacją i akredytacją z punktu widzenia polityk publicznych, dla których - oczywiście z pewnym uproszczeniem - akredytacja jest narzędziem oceny zewnętrznej, a ewaluacja co do zasady jest narzędziem oceny środowiskowej i wewnętrznej. Stąd też rozważania nie orientują się na kwestię modelu ewaluacji ani rodzajów akredytacji, procedur, specyfiki agencji akredytacyjnych. Przyjęto, że funkcjonują one zarówno w murach uczelni, jak i na niemieckim rynku akredytacyjnym, bez rozstrzygania o ich właściwościach. Autor skupił się na ukazaniu specyfiki rozwiązań niemieckich, uwzględniając jednocześnie odniesienia do polskich realiów.
\end{abstract}

Słowa kluczowe: ewaluacja; akredytacja; niemieckie szkolnictwo wyższe 
Kilka dekad temu w RFN zainicjowano dyskusję dotyczącą uczenia na jakościowo dobrym poziomie oraz jego trwałego podnoszenia w obliczu wyzwań wewnątrzkrajowych i zewnętrznych. Wówczas, tj. w latach 80. XX wieku, mankamentem uczelni niemieckich miało być tempo kształcenia i przeteoretyzowanie. Istotne były również sygnały płynące ze sfery gospodarczej oraz od państwa, wskazujące na zmianę oczekiwań względem profilu nauczania i funkcjonowania uczelni w ogólnie ujmowanej public policy ${ }^{1}$. Nie bez znaczenia była zasada kojarzenia nakładów i efektów, a to oznaczało - wzorem podmiotów gospodarczych - także wkomponowanie relacji input-output w krwioobieg uczelni ${ }^{2}$. Kolejnym wyzwaniem stała się potrzeba racjonalizacji ekonomicznej, co wymuszało zmiany modelu zarządzania i przyjęcie ofensywnej postawy względem otoczenia oraz zmiany strukturalne systemu i w ostateczności samych siebie.

W tak ujmowanym podejściu do zarządzania uniwersytetem ewaluacji przypisano kluczową rolę. Odpowiedzialność i trwałe gwarantowanie jakości scedowano na uczących, m.in. przez poszerzenie zakresu autonomii szkół i wyposażanie ich w obszerny katalog instrumentów. Równolegle upowszechniała się koncepcja university social responsibility, a wraz z nią jej horyzontalna i wertykalna dyfuzja. Nowo zdefiniowaną przestrzeń szkolnictwa zaczęto zapełniać wyzwaniami, ideami, rolami uniwersytetu, podmiotami o charakterze interesariuszy czy agencji ${ }^{3}$. Nie mogło się to zakończyć inaczej, jak napotkaniem oporu i sprzeciwu tradycyjnie zorientowanego korpusu akademickiego. Dostrzegł on zagrożenia względem środowiskowej samorządności i przeniesienia - jak kilka dekad wcześniej w przedsiębiorstwach - władzy i wpływu na nowych menedżerów szkół wyższych oraz na pion zarządczo-biurokratyczny ${ }^{4}$.

Ważną rolę w tym okresie odegrały centralne niemieckie instytucje szkolnictwa wyższego. W swych stanowiskach stale dowartościowywały społeczną

1 E. Künzel, S. Nickel, L. Zechlin, Qulitätssicherungssysteme für Hochschulen. Evaluation allein bringt's nicht!, [w:] Reformen von innen. Ein Ansto $\beta$ zur Weiterentwicklung und Umesetzung von Evaluationskonzepten, München-Mering 2000, s. 121. Zob. szerzej: K. Szewior, Akredytacja w niemieckim szkolnictwie wyższym. Zarys zagadnienia, Warszawa 2018.

2 J. Stüber, Akkreditierung von Studiengängen. Qualitätssicherung im Hochschulrecht vor dem Hintegrund der internationalen Entwicklungen im Bildungssektor, insbesondere des Bolonga-Prozesses, Frankfurt am Main 2009, s. 41.

3 Szerzej o społecznych zadaniach szkół wyższych zob. A. Kupfer, Universität und soziale Gerechtigkeit. Eine Bilanz der Hochschulreformen seit 1998, Frankfurt-New York 2004; U. Welbers, Studien Reform und Qualitätsentwicklung, [w:] Handbuch der Akkreditierung von Studiengängen. Eine Einführung für Hochschule, Politik und Berufspraxis, Hrsg. F. Bretschneider, J. Wildt, Bielefeld 2007, s. 80 i n.

4 K. Szewior, Proces Boloński - pomiędzy oczekiwaniem i środowiskowym rozczarowaniem?, [w:] Traktat Lizboński. Dobre rozwiąanie w czasach kryzysów?, red. J.J. Węc, A. Nitschke, Kraków 2018, s. 135-145. 
rolę i funkcję nauki, podkreślały konstytucyjną ochronę i zapewnienie systemowego wsparcia ze strony państwa. Jednocześnie formułowały jednak oczekiwania, które wbrew pobieżnym środowiskowym wyobrażeniom nie szkodzą nauce ani szkolnictwu. Mianowicie instytucje te i społeczeństwo niemieckie przypisały uczelniom, by nie stwierdzić bardziej jednoznacznie, że dobitnie to wyartykułowały, iż te z racji generowania wiedzy i zarządzania nią posiadają władzę i możliwość wywierania społecznego wpływu. Stąd postulat, w myśl nowego publicznego zarządzania, że dzierżąc ją w sposób odpowiedzialny, celowy i transparentny, powinny rozliczyć się z niej przed społeczeństwem ${ }^{5}$. Dlatego zobligowano szkoły do budowania własnych quality management systems. Na znaczeniu zyskało społeczne rozłożenie odpowiedzialności oraz kooperacja $\mathrm{z}$ interesariuszami. W praktyce oznaczało to przejście $\mathrm{do}^{6}$ :

- oceny jakościowej procesu kształcenia,

- ewaluacji wyników kształcenia metodą ex post,

- zorientowania na efekty końcowe (w tym współdefiniowane zewnętrznie),

- podejścia procesowego, zarówno w odniesieniu do realizacji toku studiów, jak i wewnętrznych systemów zapewnienia jakości,

- ujmowania jakości wieloobszarowo i wieloczynnikowo,

- zorientowania zarządzania szkołą wyższą na podnoszenie jakości realizacji toku studiów,

- budowania systemów zarządzania w wymiarze unijnym, krajowym i uczelnianym,

- nadzoru realizowanego przez podmioty publiczno-prywatne działające w imieniu państwa.

Doświadczenie niemieckie unaoczniło zmianę w podziale kompetencji w sektorze szkolnictwa wyższego. Odpaństwowienie kontroli i jednocześnie zachowanie przy instytucji państwa finalnej odpowiedzialności za szkolnictwo jako całości zachodziło równolegle z przejmowaniem roli nadzorczej przez agencje akredytacyjne. Stały się one kolejnym graczem systemu, zmuszając do

5 M. Brockmeier, Vertrauen in die Wissenschaft. Bericht der Vorsitzenden zu aktuellen Tendenzen im Wissenschaftssystem, WR Wissenschaftsrat, Die Vorsitzende, Berlin 20.10.2017, Herbstsitzungen des Wissenschaftsrates, s. 1-3.

6 A. Fritz, Das Akkreditierungssystem an deutschen Universitäten. Qualität sichern, Vielfalt fördern, Transparenz schaffen, Vergleichbarkeit erreichen!?, Marburg 2010, s. 46, 51; H.-U. Erichsen, Institutionelle Verankerung und Rechtsrahmen der Akkreditierungs, [w:] Handbuch der Akkreditierung von Studiengängen..., s. 121-122; C. Klockner, Vortrag Professor Dr. h.c. Clemens Klockner, Vicepräsident der Hochschulerektorenkonferenz „Qualitätssicherung durch Evaluation als Aufgabe der Hochschulen“, [w:] Qualität an Hochschulen. Fachtagung der Universität Kaiserslautern und der Hochschulrektorenkonferenz Kasierslautern, 28./29. September 1998, „Beiträge zur Hochschupolitik“1999, Nr. 1, s. 19. 
szukania nowego stanu równowagi, wzajemnego poznawania się i dostosowywania ${ }^{7}$. W wielu przypadkach agencje akredytacyjne ustawiały się w szeregu „chłopca do bicia" tudzież godnego wyszydzenia przez uniwersytecki mainstream. Ich jedynym antidotum i środkiem skutecznego oddziaływania, przynajmniej w początkowych latach funkcjonowania, było wówczas koncesjonowanie licencji na prowadzenie studiów oraz świadczenie rzetelnej pracy, przenoszenie na grunt niemiecki dobrych praktyk i doświadczeń z innych kręgów kulturowych i ładów akredytacyjnych.

W takich okolicznościach poświadczenie zapewnienia standardu i jakości nauczania przeszło na uczelnie, a finalnie - na agencje ${ }^{8}$. Patrząc przez pryzmat polityk publicznych, należy stwierdzić, że nie czyniono tego wyłącznie w jednorazowym akcie podejmowania decyzji o udzieleniu bądź odmowie akredytacji, lecz implementując i propagując politykę jakości i zarazem dążąc do tego, by stała się kluczowym elementem zarządzania nowoczesnej szkoły wyższej. Z drugiej strony podejmowano starania, by także w ewaluacji dostrzec potencjał integrujący środowisko i optymalizujący wykorzystanie jego zasobów. Tym samym ewaluacja miała stać się kołem zamachowym doskonalenia uczelni, jej kultury akademickiej w sferach nauczania i badań naukowych. Powinna być również „wewnętrzną" odpowiedzią szkoły wyższej na „zewnętrzną" akredytację. W takim ułożeniu autonomicznych relacji nie ma konfliktu interesów, a dodatkowo pozwoli to spełnić postulat wyrażony np. przez Manuela Pietzonka, by przesadnie nie dowartościowywać procesu akredytacji poprzez mocne określenia sugerujące przejmowanie przez agencje akredytacyjne kompetencji decyzyjnych i zarządczych nad kierunkiem studiów, ponieważ akredytacja powinna oddziaływać przede wszystkim subsydiarnie ${ }^{9}$.

Nie tylko w RFN wprowadzenie i praktykowanie akredytacji przez szereg lat współbrzmiało ze społeczną debatą oraz apelem o zrozumienie konieczności i środowiskowy kompromis wokół tego, czym jest jakość kształcenia, czy jest mierzalna, czym jest i jaką rolę powinna spełniać środowiskowa ewaluacja czy wręcz środowiskowo pojmowana i realizowana akredytacja. Tymczasem jest to wyzwanie kluczowe, gdyż określa zachowanie uczelni i nauczycieli akademickich oraz podejście do ewaluacji i akredytacji. Dominujący dziś pluralizm pojęć, ale też brak świadomości i ugruntowanej przedmiotowej wiedzy pozwalają

7 M. Pietzonka, Gestaltung von Studiengängen im Zeichen von Bolonga. Die Umsetzung der Studienreform und die Wirksamkeit der Akkreditierung, Wiesbaden 2014, s. 63-65.

8 A. Fritz, op. cit., s. 37; J. Stüber, op. cit., s. 42. P. Pasternack, Qualitätssicherung und Qualitätsentwicklung, [w:] Handbuch der Akkreditierung von Studiengängen..., s. 87.

9 M. Pietzonka, op. cit., s. 53, 65-67. 
uczelniom na samowiedne określenie w swych strategiach rozwoju i systemach zapewnienia jakości, czym jest dla nich jakość kształcenia i jaką treścią ją wypełnią. Przenosząc tę kwestię na grunt wyłącznie polski, warto dostrzec, że tylko w sporadycznych przypadkach kryteria jakościowe można wyczytać z nielicznych standardów kształcenia, ram kwalifikacji, branżowych uregulowań. Poza tym jakość kształcenia jawi się jako przestrzeń do zagospodarowania poprzez właściwości programu, całościową ofertę i realizację studiów. I właśnie w tym obszarze trzeba wiązać autonomię z odpowiedzialnością wszystkich podmiotów zaangażowanych w szkolnictwo wyższe ${ }^{10}$. Ważne jest zabezpieczenie i jednoczesne oczekiwanie rozsądnego kooperowania szkół wyższych z interesariuszami, by posiłkując się ich wkładem, nie dały się im sprowadzić do roli wykonawcy woli i producenta informacji naukowej oraz by nie ulegały jednostkowym presjom grup społecznych czy wreszcie często własnej pokusie szybkiej utylitarności kosztem długofalowego i kosztownego rozwijania kapitału intelektualnego studentów ${ }^{11}$.

$\mathrm{Na}$ tym polu kluczowa powinna być środowiskowa ewaluacja, tj. czyniona przez szkolnictwo wyższe i w jego interesie. Jej uczciwa forma wymaga autonomii i podmiotowości w relacji do instytucji państwa i społeczeństwa. Poprzez ewaluację, która siłą rzeczy musi skutkować sprawozdawczością, uzyskuje się szansę nadania swym działaniom transparentności, ale i racjonalności. Ewaluacja w uczelnianej rzeczywistości służy ocenie wyników i warunków nauczania, dlatego powinna stanowić punkt wyjścia w zarządzaniu „zorientowanym na jakość". W dobrej ewaluacji nie może zabraknąć dyskursu, transparentności, zwrotnej oceny, środowiskowego kontekstu. Ewaluacja ma sens, gdy jest należycie zogniskowana na sferę realizacji toku studiów, gdy jest rzetelna, przydatna, wiarygodna, włączająca i w sposób przekonujący skłania do podejmowania dalszych inicjatyw prorozwojowych w zakresie kształcenia, prowadzenia uczelni czy stosowania narzędzi ewaluacyjnej diagnozy ${ }^{12}$.

Bez wątpienia względem akredytacji ewaluacja jest procesem zarazem pierwotnym i szerszym, bazuje na autorefleksji, samoocenie, samodoskonaleniu.

10 Begrüßung und Eröffnung. Professor Dr. Günter Warnecke Präsident der Universität Kaiserslautern, [w:] Qualität an Hochschulen..., s. 9.

11 I. Srubar, Die Unwissensgesellschaft. Moderne nach dem Verlust von Alternativen, [w:] Zur Kritik der Wissensgesellschaft, Hrsg. D. Tänzler, H. Knoblauch, H.-G. Soeffner, Konstanz 2006, s. 139-154; S. Garcia, Die Konstruktion des europäischen Hochschulraums, [w:] Humboldts Albtraum. Bologna-Prozess und seine Folgen, Hrsg. F. Schultheis, P.-F. Cousin, M.R. i Escoda, Konstanz 2008, s. 69-70, 76; A. Fritz, op. cit., s. 37-39.

12 F. Ziegle, Evaluation von Steuerungsinstrumenten/Zielvereinbarungen, [w:] Qualitätssicherung im europäischen Kontext: Akkreditierung, Evaluierung, Arbeitsgruppe im Sprechkreis der Universitätskanzler, Weimar 2005, s. 29-38. 
Niezależnie od tego, czy jest prowadzona z zewnątrz czy w ramach działań własnych szkoły, cechuje ją doradczy i rekomendacyjny charakter ${ }^{13}$. Wprowadzenie ewaluacji oznacza budowanie nowego modelu zarządzania zorientowanego na cel, kontrolę, gromadzenie, przetwarzanie i weryfikację danych, środowiskową kooperację ${ }^{14}$. Ewaluacja ma stanowić dla uczelni wiarygodną podstawę w podejmowaniu racjonalnych decyzji, inwestycji i strategicznego planowania. Należy mieć na uwadze zachowanie właściwych relacji pomiędzy wewnętrznymi i zewnętrznymi mechanizmami nadzoru (akredytacją, certyfikowaniem, audytem). Narzędzia ewaluacyjno-akredytacyjne są składową całościowo ujmowanego projakościowego funkcjonowania uczelni i jej atutem, dlatego nie powinny być zagarnięte jednostronnie przez podmioty zewnętrzne - państwo i jego agendy.

Kierując się paradygmatem środowiskowej podmiotowości, należy propagować odpowiedzialną ewaluację dydaktyki, by przestał obowiązywać zarzut sformułowany w 1965 roku przez Ralfa Dahrendorfa, mówiący o tym, że głównym problemem szkół jest to, iż nie chcą przejąć na siebie odpowiedzialności za złe wyniki szkolne ${ }^{15}$.

Z uwagi na zmianę modelu funkcjonowania państwa dziś nie da się urzeczywistnić idei Mitverantwortung bez uspołecznienia jednocześnie wpisującego się w sieciowość relacji społeczeństwa wiedzy ${ }^{16}$. Wiarygodna ewaluacja musi być skojarzona z takim sposobem kierowania jednostką, które na zewnątrz powinno przekonywać o naszej autentycznej odpowiedzialności. To zaś oznacza m.in. odpowiednie ukształtowanie ustroju wewnętrznego szkół wyższych (bardziej spłaszczone relacje, współdziałanie, współdecydowanie, współodpowiedzialność) oraz poukładanie szeregu kontaktów pomiędzy uczelnią jako instytucją

13 J.W. Gerlach, Akkreditierung von privaten Hochschulen, [w:] Qualitätssicherung im europäischen Kontext: Akkreditierung, Evaluierung, Weimar 2005, s. 47-50.

14 M. Meinhold, Professor Dr. Marianne Meinhold. Von der Evaluation zur Qualitätssicherung, [w:] Im Aufbruch. Evaluation an Hochschulen. Fachtagung der Evangelischen Fachhochschule Berlin und der Hochschulrektorenkonferenz Berlin, 17./18. Februar 2000, „Beiträge zur Hochschulpolitik“ 2000, Nr. 9, s. 79. Joachim Hermann opisał model procesu zarządzania jakością w sferze akademickiego nauczania, wykorzystując normy DIN EN ISO 90008: 2000. Zob. J. Hermann, Prozessmodell für ein institutionelles Qualitätsmanagement der Lehre an Hochschulen, [w:] Qualität durch Chancengleichheit. Gleichstellung als strategischer Faktor im Qualitätsmanagement technischer Universität, Hrsg. M. Esch, J. Hermann, Bielefeld 2008, s. 135-143.

15 S. Volkholz, Verantwortung als zentrale Kategorie der Bildungsinstitutionen fur die Wissenschaft, [w:] Die Verfasstheit der Wissensgesellschaft, konzipiert und bearbeitet von K. Gerolf, A. Ulrich, Munster 2006, s. 215 (szerzej: s. 214-223).

16 S. Harris-Huemmert, L. Mitterauer, P. Pohlenz, Evaluation im Kontext der Hochschule, [w:] Evaluation in Deutschland und Österreich. Stand und Entwicklungsperspektiven in den Arbeitsfeldern der DeGEval - Gesellschaft für Evaluation, Hrsg. W. Böttcher, Ch. Kerlen, P. Maats, O. Schwab, S. Sheikh, Münster-New York 2014, s. 107-115. 
i ośrodkiem wiedzy a otoczeniem społecznym i w konsekwencji państwem ${ }^{17}$. Wydaje się to zgodne ze zmianą ról pomiędzy uniwersytetem i jego społecznym zapleczem, lecz także z ich urynkowieniem i prywatyzacją ${ }^{18}$. Wiedza stała się towarem i przedmiotem obrotu na (quasi)rynku edukacyjnym ${ }^{19}$. O ile w minionym okresie to uniwersytet i nauka przemawiały do społeczeństwa, o tyle dziś - jak zauważa Helga Nowotny - „społeczeństwo odpowiada nauce”. Ponieważ linie dzielące te dwa światy są przepuszczalne, a granice, w których wiedza powstawała i była gromadzona, uległy drastycznemu rozszerzeniu, a być może nawet zniknęły, to wiedza jest nieustannie przez społeczeństwo sprawdzana, weryfikowana i kwestionowana. Interesy społeczeństwa powinny być zatem uwzględniane. Czy naruszy to obiektywizm poznania naukowego? ${ }^{20}$

Zaufanie również w procesie akredytacji odgrywa kluczową rolę, a zobowiązuje ją do tego sam źródłosłów. Z perspektywy polityki publicznej akredytacja jest zewnętrzną formą ewaluacji, jednakże niesie za sobą skutki prawne i finansowe. Nie tylko w RFN, ale i w Polsce akredytacja jest stałym narzędziem w ręku państwa wykorzystywanym w odniesieniu do uruchamiania studiów, oceny realizacji toku kształcenia, spełniania przez uczelnię warunków formalnych i merytorycznych standardów. Jej specyfika i środowiskowe uznanie zależą od: charakteru rynku akredytacyjnego, zaangażowania przedstawicieli szkół wyższych i grona interesariuszy, otwartości na innowacyjne podejścia edukacyjne, modelu uczelni i jej polityki jakości.

Myśląc o wyzwaniach systemowych, należy pamiętać o Europejskim Obszarze Szkolnictwa Wyższego, umiędzynarodowieniu, uczynieniu ze szkolnictwa wyższego jednego z segmentów społeczeństwa wiedzy ${ }^{21}$. Wymagają one specyficznego sterowania, podejścia strategicznego, zestandaryzowanej usługi o porównywalnej czy mierzalnej (?) jakości. Te skojarzenia ze sferą gospodarczą, choć wymuszone, są jak najbardziej uzasadnione. Na poziomie gospodarki narodowej międzynarodowe standardy kształcenia są warunkiem czterech europejskich wolności: pracy, kapitału, dóbr i usług. Natomiast na poziomie

17 M. Meinhold, op. cit., s. 80.

18 K. Szewior, Europejski Obszar Szkolnictwa Wyższego - mini rynek Unii Europejskiej $w$ dobie zmian modelu integracji, [w:] Integracja europejska. Gtówne obszary badawcze, red. K.A. Wojtaszczyk, J. Tymanowski, P. Stawarz, Warszawa 2015, s. 415-431.

19 H. Bethge, Die Bildungsmärkte der Wissensgesellschaft. Public-Private-Partnership an Schulen, [w:] „Die Wissensgesellschaft“. Mythos, Ideologie oder Realität?, Hrsg. U.H. Bittlingmayer, U. Bauer, Wiesbaden 2006, s. 401-428.

20 H. Nowotny, Wissenschaft neu denken: Vom verlasslichen Wissen zum gesellschaftlich robusten Wissen, [w:] Die Verfasstheit der Wissensgesellschaft, s. 24-33.

21 H.-D. Kübler, Mythos Wissensgesellschaft. Gesellschaftlicher Wandel zwischen Information, Medien und Wissen. Eine Einfuhrung, Wiesbadaen 2005, s. 159-193. 
przedsiębiorstw umożliwiają one dalszy rozwój wiedzy, organizacji, komunikację w zróżnicowanym środowisku, outsourcing i powiązanie wielu niezależnych szkół wyższych w sieć badawczo-dydaktycznąa ${ }^{22}$. Mimo że ewaluacja i akredytacja nadal pozostają domeną narodowych polityk i kompetencji ${ }^{23}$, to fakt umiędzynarodowienia przestrzeni szkolnictwa wyższego oraz ponadnarodowe zestandaryzowanie ram kryterialnych akredytacji daje szansę, by optymalizować własne praktyki ewaluacyjne. Jest to szczególnie ważne w procesie przechodzenia w stronę modelów (pro)rozwojowych ${ }^{24}$.

Poprzez akredytację w RFN rozumie się postępowanie służące formalnemu uznaniu kompetencji organizacji do osiągania specyficznych wyników, tym samym służy ona stwierdzeniu, czy „badany przedmiot/obszar odpowiada określonemu (przyjętemu) standardowi”. W jej opisie wskazuje się najczęściej, że jest procesem formalnym, jest przeprowadzana przez niezależną instytucję, zawiera elementy zarówno wewnętrznej, jak i zewnętrznej ewaluacji ${ }^{25}$.

Akredytacja znajduje zastsowanie $\mathrm{w}$ wielu obszarach, a akademicki świat nie wiedzie pod tym względem prymu. Współczesne zarządzanie niemalże jako regułę scedowało przeprowadzanie akredytacji z instytucji państwa na podmioty publiczno-prywatne działające na jego rzecz i w jego imieniu. W Niemczech transparentność przyjętego rozwiązania jest zaszczepiona w mechanizmie nadzoru nad agencjami. Przez szereg lat rolę tę pełniła Rada Akredytacji z siedzibą w Bonn, a obecnie przynależy ona do ENQA i EQAR.

Należy mieć na uwadze niemiecką różnorodność wariantów akredytacji: programową, systemową, instytucjonalną, a także moment jej przeprowadzania względem cyklu studiów oraz fazy budowy uczelnianych struktur administracyjnych i samego systemu zapewniania jakości. W praktyce i literaturze przedmiotu panuje przekonanie, że akredytacja zawsze powinna uzupełniać subsydiarnie proces wewnątrzuczelnianej ewaluacji. Dodatnia wartość akredytacji ujawni się wówczas w zestawieniu jej wyników z tymi uzyskiwanymi w innych ośrodkach akademickich czy na odmiennych kierunkach studiów oraz w spojrzeniu peer review i zaangażowaniu interesariuszy reprezentujących szersze otoczenie społeczne. Tym samym należy podzielić pogląd Helmuta Konrada, że akredytacja chroni studentów (klientów) przed ofertą poniżej środowiskowego standardu,

22 K. Gerolf, Zur Debate: Bildung in der Netwerkgesellschaft, [w:] Die Verfasstheit der Wissensgesellschaft, s. 208-213.

23 A. Schade, F. Bretschneider, Der Akkreditierungsrat, [w:] Handbuch der Akkreditierung von Studiengängen..., s. 138-139.

24 L. Korporowicz, Zmienne losy polskiej ewaluacji. Pomiędzy nadzieja, animacja i konfuzja, [w:] Ewaluacja w edukacji, red. B. Niemierko, Kraków 2011.

25 A. Fritz, op. cit., s. 48. 
zapewnia transparentność i dostarcza wiedzy o specyfice usługi edukacyjnej. Co więcej, powinna pomagać uczelni w krytycznej ocenie czy we wdrażaniu projakościowych rozwiązań. Należycie prowadzona akredytacja wnosi do szkoły aktualną wiedzę prawną, a także wiedzę o metodach nauczania i stanie rozwoju dyscyplin. $Z$ uwagi na zróżnicowanie studenckich ław podkreśla się też fakt, że akredytacje mające międzynarodowy charakter - prowadzone przez agencje spoza państw niemieckiego obszaru językowego i wielonarodowe składy zespołów, mające na celu dokonanie oceny kwestii wielokulturowości w treści nauczania i w życiu uczelni - uwiarygodniają rodzime szkolnictwo wyższe w oczach potencjalnych studentów pochodzących z innych krajów i regionów świata ${ }^{26}$.

Z uwagi na wewnętrzny charakter ewaluacji i zewnętrzny charakter akredytacji występują pomiędzy nimi napięcia, najczęściej na płaszczyźnie metodologii pracy, diagnozy sytuacji oraz skuteczności oddziaływania. Stan ten nie dyskredytuje czegokolwiek, dowodzi jedynie autonomii stron oraz potrzeby wzajemnego wypracowywania standardów pracy. Nie musi to oznaczać zrównania, bo przecież uczelnie i agencje rozwijają własne zakresy kompetencji, warunki oceny, narzędzia diagnozy. Jednakże np. w Niemczech w początkowym okresie rozwoju systemu akredytacji dostrzegalnym problemem była „akademicka ortodoksja" nakazująca prowadzenie kierunku studiów według upodobań agencyjnych ekspertów czy uniwersyteckiego mainstreamu. Dlatego dla uniknięcia takich sytuacji zaczęto silniej standaryzować procedury i kryteria oceny, co z kolei spotkało się z zarzutem lansowania „zestandaryzowanych minimalnych kryteriów". Czerpiąc doświadczenia dodatkowo z Polski, wypada uznać, że pogląd ten nie jest nieuzasadniony. Wprawdzie faktem jest, iż udzielenie akredytacji orzeka o spełnieniu koniecznych (minimalnych) wymogów o charakterze prawnym i merytorycznym, w żaden sposób jednak nie pozbawia uczelni prawa do poszukiwania własnej specyfiki badawczej i dydaktycznej, zabiegania o wyższy standard nauczania i całościowego prowadzenia studiów w sposób bardziej atrakcyjny. Agencje akredytacyjne dają temu wyraz, podnosząc ocenę. W Polsce w myśl obowiązujących przepisów prawa ocena akredytacyjna (programowa) może wiązać się z nadaniem Certyfikatów Doskonałości Kształcenia w czterech zakresach: Doskonały kierunek; Zawsze dla studenta; Otwarty na świat; Partner dla rozwoju ${ }^{27}$.

26 H. Konrad, Funktion, Bedeutung, Ausrichtung und Folgen der Akkreditierung, [w:] Qualitätssicherung im europäischen Kontext: Akkreditierung, Evaluierung, Weimar 2005, s. 41-42.

27 Statut Polskiej Komisji Akredytacyjnej (tekst ujednolicony uwzględniający zmiany wprowadzone uchwałą Polskiej Komisji Akredytacyjnej z dnia 18 lutego 2019 r. nr 1/2019), załącznik do uchwały nr 4/2018 Polskiej Komisji Akredytacyjnej z dnia 13 grudnia 2018 r., załącznik nr 4 do Statutu Polskiej Komisji Akredytacyjnej. 
Warto pamiętać, że uczestnicy procesów ewaluacyjno-akredytacyjnych nie mają (nie powinni mieć) sprzecznych interesów. Jak stwierdziła Barbara Kehm, kluczowe kompetencje można multiplikować, integrować czy wręcz formułować dla dopełnienia wymogów formalnych. W realiach niemieckich jest to tym bardziej możliwe, gdyż agencje akredytacyjne świadczą stosunkowo szeroki katalog usług (akredytację, ewaluację, certyfikowanie, audyt, doradztwo, szkolenia), a jednocześnie prowadzą działalność analityczno-publikacyjną. Są też powiązane relatywnie dobrze $\mathrm{z}$ otoczeniem społecznym i bardzo dobrze rozwiniętym rodzimym przemysłem. Szereg z nich pochodzi z krajów niemieckojęzycznych i/lub w nich funkcjonuje; poza tym agencje te są aktywne na europejskim i międzynarodowym rynku akredytacyjnym. Ogół tych atutów pozwala im wejść $\mathrm{w}$ rolę merytorycznego doradcy ${ }^{28}$. Bardzo wyraźnie widać to w orzecznictwie oraz w praktyce i dokumentach agencji akredytacyjnych. Stwierdza się w nich, że jakość kształcenia jest centralnym zadaniem szkół, podobnie jak dokumentowanie wyników i prowadzonych w tym zakresie działań. Do instrumentarium pozauczelnianego wsparcia zalicza się zewnętrznych i wewnętrznych peer review, standaryzację postępowań, kontrolę zorientowaną na naukę, profesjonalizację zarządzania ${ }^{29}$. Zobowiązaniem agencji jest również doradztwo i prowadzenie uczelni na ścieżce rozwoju kultury jakości przy jak najmniejszym naruszaniu jej autonomii i integralności naukowo-dydaktycznej ${ }^{30}$. Właściwe do tego są atmosfera dialogu i partnerstwa oraz funkcjonowanie w sposób transparentny w autonomicznym i odpowiedzialnym środowisku.

Co powinno znajdować się pomiędzy ewaluacją i akredytacją? Bez wątpienia wzajemne zaufanie, podmiotowość stron i zrozumienie kontekstu działania. Uświadomienie sobie faktu uwarunkowań zachodzących w świecie, a najdobitniej zdefiniowanych w pojęciach społeczeństwa i gospodarki wiedzy, a także zmiany modelu funkcjonowania państw i sfery publicznej powinno wystarczyć, by nie dostrzegać $w$ agencjach akredytacyjnych jedynie ciała obcego i wrogiego szkolnictwu wyższemu. $\mathrm{Z}$ drugiej strony agencje akredytacyjne muszą mieć świadomość faktu, że samoocena środowiska akademickiego jest zjawiskiem już utrwalonym i przez dziesięciolecia nie zdyskredytowała ich społecznej funkcji ani statusu. Wzajemne zaufanie powinno odnosić się przede wszystkim do nadania stronom autonomii w działaniu i budowaniu własnych struktur, a także

28 B.M. Kehm, Akkreditierungsagenturen in Deutschland, [w:] Handbuch der Akkreditierung von Studiengängen. Eine Einführung für Hochschule, Politik und Berufspraxis, Hrsg. F. Bretschneider, J. Wildt, Bielefeld 2007, s. 160.

29 Entschließung der 21. Mitgliederversammlung der HRK am 8. November 2016 in Mainz. Neuordnung des Akkreditierungssystems, HRK Hochschulrektorenkonferenz, s. 2.

30 Ibidem, s. 3-7. 
do przyjęcia za wiarygodne zewaluowanego i zakredytowanego oraz opisanego stanu rzeczy. W tym będzie się wyrażać nasza wzajemna podmiotowość, która pozwoli łatwiej kooperować uczelni zarówno z agencjami, jak i z całym jej otoczeniem na rzecz podnoszenia jakości badań naukowych oraz wiązania ich w sposób najbardziej optymalny z procesem nauczania.

\section{BIBLIOGRAFIA}

Begrüßung und Eröffnung. Professor Dr. Günter Warnecke Präsident der Universität Kaiserslautern, [w:] Qualität an Hochschulen. Fachtagung der Universität Kaiserslautern und der Hochschulrektorenkonferenz Kasierslautern, 28./29. September 1998, „Beiträge zur Hochschupolitik“ 1999, Nr. 1.

Bethge H., Die Bildungsmärkte der Wissensgesellschaft. Public-Private-Partnership an Schulen, [w:] „Die Wissensgesellschaft“. Mythos, Ideologie oder Realität?, Hrsg. U.H. Bittlingmayer, U. Bauer, Wiesbaden 2006.

Brockmeier M., Vertrauen in die Wissenschaft. Bericht der Vorsitzenden zu aktuellen Tendenzen im Wissenschaftssystem, WR Wissenschaftsrat, Die Vorsitzende, Berlin 20.10.2017, Herbstsitzungen des Wissenschaftsrates.

Entschließung der 21. Mitgliederversammlung der HRK am 8. November 2016 in Mainz. Neuordnung des Akkreditierungssystems, HRK Hochschulrektorenkonferenz.

Erichsen H.-U., Institutionelle Verankerung und Rechtsrahmen der Akkreditierungs, [w:] Handbuch der Akkreditierung von Studiengängen. Eine Einführung für Hochschule, Politik und Berufspraxis, Hrsg. F. Bretschneider, J. Wildt, Bielefeld 2007.

Fritz A., Das Akkreditierungssystem an deutschen Universitäten. Qualität sichern, Vielfalt fördern, Transparenz schaffen, Vergleichbarkeit erreichen!?, Marburg 2010.

Garcia S., Die Konstruktion des europäischen Hochschulraums, [w:] Humboldts Albtraum. Bologna-Prozess und seine Folgen, Hrsg. F. Schultheis, P.-F. Cousin, M.R. i Escoda, Konstanz 2008.

Gerlach W., Akkreditierung von privaten Hochschulen, [w:] Qualitätssicherung im europäischen Kontext: Akkreditierung, Evaluierung, Weimar 2005.

Gerolf K., Zur Debate: Bildung in der Netwerkgesellschaft, [w:] Die Verfasstheit der Wissensgesellschaft, konzipiert und bearbeitet von K. Gerolf, A. Ulrich, Munster 2006.

Harris-Huemmert S., Mitterauer L., Pohlenz P., Evaluation im Kontext der Hochschule, [w:] Evaluation in Deutschland und Österreich. Stand und Entwicklungsperspektiven in den Arbeitsfeldern der DeGEval - Gesellschaft für Evaluation, Hrsg. W. Böttcher, Ch. Kerlen, P. Maats, O. Schwab, S. Sheikh, Münster-New York 2014.

Hermann J., Prozessmodell für ein institutionelles Qualitätsmanagement der Lehre an Hochschulen, [w:] Qualität durch Chancengleichheit. Gleichstellung als strategischer Faktor im Qualitätsmanagement technischer Universität, Hrsg. M. Esch, J. Hermann, Bielefeld 2008. 
Kehm B.M., Akkreditierungsagenturen in Deutschland, [w:] Handbuch der Akkreditierung von Studiengängen. Eine Einführung für Hochschule, Politikund Berufspraxis, Hrsg. F. Bretschneider, J. Wildt, Bielefeld 2007.

Klockner C., Vortrag Professor Dr. h.c. Clemens Klockner, Vicepräsident der Hochschulerektorenkonferenz „Qualitätssicherung durch Evaluation als Aufgabe der Hochschulen“, [w:] Qualität an Hochschulen. Fachtagung der Universität Kaiserslautern und der Hochschulrektorenkonferenz Kasierslautern, 28./29. September 1998, „Beiträge zur Hochschupolitik“ 1999, Nr. 1.

Konrad H., Funktion, Bedeutung, Ausrichtung und Folgen der Akkreditierung, [w:] Qualitätssicherung im europäischen Kontext: Akkreditierung, Evaluierung, Weimar 2005.

Korporowicz L., Zmienne losy polskiej ewaluacji. Pomiędzy nadzieja, animacja $i$ konfuzją, [w:] Ewaluacja w edukacji, red. B. Niemierko, Kraków 2011.

Kupfer A., Universität und soziale Gerechtigkeit. Eine Bilanz der Hochschulreformen seit 1998, Frankfurt-New York 2004.

Kübler H.-D., Mythos Wissensgesellschaft. Gesellschaftlicher Wandel zwischen Information, Medien und Wissen. Eine Einfuhrung, Wiesbadaen 2005.

Künzel E., Nickel S., Zechlin L., Qulitätssicherungssysteme für Hochschulen. Evaluation allein bringt's nicht!, [w:] Reformen von innen. Ein Ansto $\beta$ zur Weiterentwicklung und Umesetzung von Evaluationskonzepten, München-Mering 2000.

Meinhold M., Professor Dr. Marianne Meinhold. Von der Evaluation zur Qualitätssicherung, [w:] Im Aufbruch. Evaluation an Hochschulen. Fachtagung der Evangelischen Fachhochschule Berlin und der Hochschulrektorenkonferenz Berlin, 17./18. Februar 2000, „Beiträge zur Hochschulpolitik“ 2000, Nr. 9.

Nowotny H., Wissenschaft neu denken: Vom verlasslichen Wissen zum gesellschaftlich robusten Wissen, [w:] Die Verfasstheit der Wissensgesellschaft, konzipiert und bearbeitet von K. Gerolf, A. Ulrich, Munster 2006.

Pasternack P., Qualitätssicherung und Qualitätsentwicklung, [w:] Handbuch der Akkreditierung von Studiengängen. Eine Einführung für Hochschule, Politik und Berufspraxis, Hrsg. F. Bretschneider, J. Wildt, Bielefeld 2007.

Pietzonka M., Gestaltung von Studiengängen im Zeichen von Bolonga. Die Umsetzung der Studienreform und die Wirksamkeit der Akkreditierung, Wiesbaden 2014.

Schade A., Bretschneider F., Der Akkreditierungsrat, [w:] Handbuch der Akkreditierung von Studiengängen. Eine Einführung für Hochschule, Politik und Berufspraxis, Hrsg. F. Bretschneider, J. Wildt, Bielefeld 2007.

Srubar I., Die Unwissensgesellschaft. Moderne nach dem Verlust von Alternativen, [w:] Zur Kritik der Wissensgesellschaft, Hrsg. D. Tänzler, H. Knoblauch, H.-G. Soeffner, Konstanz 2006.

Statut Polskiej Komisji Akredytacyjnej (tekst ujednolicony, uwzględniający zmiany wprowadzone uchwałą polskiej komisji akredytacyjnej z dnia 18 lutego 2019 r. nr 1/2019), załącznik do uchwały nr 4/2018 Polskiej Komisji Akredytacyjnej z dnia 13 grudnia 2018 r., załącznik nr 4 do Statutu Polskiej Komisji Akredytacyjnej. 
Stüber J., Akkreditierung von Studiengängen. Qualitätssicherung im Hochschulrecht vor dem Hintegrund der internationalen Entwicklungen im Bildungssektor, insbesondere des Bolonga-Prozesses, Frankfurt am Main 2009.

Szewior K., Akredytacja w niemieckim szkolnictwie wyższym. Zarys zagadnienia, Warszawa 2018.

Szewior K., Europejski Obszar Szkolnictwa Wyższego - mini rynek Unii Europejskiej w dobie zmian modelu integracji, [w:] Integracja europejska. Gtówne obszary badawcze, red. K.A. Wojtaszczyk, J. Tymanowski, P. Stawarz, Warszawa 2015.

Szewior K., Proces Boloński - pomiędzy oczekiwaniem i środowiskowym rozczarowaniem?, [w:] Traktat Lizboński. Dobre rozwiązanie w czasach kryzysów?, red. J.J. Węc, A. Nitschke, Kraków 2018.

Volkholz S., Verantwortung als zentrale Kategorie der Bildungsinstitutionen fur die Wissenschaft, [w:] Die Verfasstheit der Wissensgesellschaft, konzipiert und bearbeitet von K. Gerolf, A. Ulrich, Munster 2006

Welbers U., Studien Reform und Qualitätsentwicklung, [w:] Handbuch der Akkreditierung von Studiengängen. Eine Einführung für Hochschule, Politikund Berufspraxis, Hrsg. F. Bretschneider, J. Wildt, Bielefeld 2007.

Ziegle F., Evaluation von Steuerungsinstrumenten/Zielvereinbarungen, [w:] Qualitätssicherung im europäischen Kontext: Akkreditierung, Evaluierung, Arbeitsgruppe im Sprechkreis der Universitätskanzler, Weimar 2005.

Summary: The article attempts to present key aspects of evaluation and accreditation in German higher education, which emerged during the implementation of accreditation procedures and building a nationwide system of supervision over higher education. The essence of considerations was to demonstrate the relationship between evaluation and accreditation from the point of view of public policies, for which - obviously with a certain simplification - accreditation is an external appraisal implement, and evaluation is - as a rule - an internal implement. The content of the article does not refer to the essence of the evaluation model, nor the types of accreditation, procedures, and the specifics of accreditation agencies. It has been assumed that accreditation and evaluation exist both at the university and on the German accreditation market without specifying their properties. The author focused on the specifics of German solutions, including on references to Polish realities.

Keywords: evaluation; accreditation; German higher education 